\title{
KONOTATIF CIGULU-CIGULU DALAM BAHASA MELAYU MANADO (BMM)
}

Oleh

\author{
Willem Hanny Rawung \\ Emal: willemhannyrawung@yahoo.com \\ Dr. Leika M.V. Kalangi, MS \\ Email: leikamvk17@gmail.com \\ Dr. Rina Pamantung, M.Hum \\ Email: r.pamantung@yahoo.com
}

\begin{abstract}
Cigulu-cigulu is a form of a riddle game. A question or a statement was delivered and then the other person or the interlocuters must find the appropiate answer or the respond for the said question or statement. Cigulu-cigulu is the abbreviated form of "cigi kong gulunggulung in Manado Malay (BMM), If translated to Bahasa Indonesia it means "tarik lalu digulung" (pull then roll). The research method used to find connotative meanings in cigulucigulu is a qualitative descriptive method with the intention of understanding phenomena experienced by informants such as behavior, perception, motivation, etc. by means of descriptions in the form of words and language in a specific context that is natural and by utilizing natural methods. The results showed that in cigulu-cigulu found connotative meaning both positive and negative. Positive when statements / questions are submitted or answers to statements / statements; vice versa. Generally cigulu-cigulu associated with food. The food in question is typical or traditional food from Manado. Semantically this is motivated because Manado have varieties of delicious food. Manadonese people are also known to likely state everything directly, not ashamed to express something "taboo" which for some other communities / cultures are considered uncultured or even forbidden to say.
\end{abstract}

Keywords: cigulu-cigulu, BMM, connotative meaning

\section{PENDAHULUAN}

Zaman dulu (sekitar 15 tahun yang lalu) sebelum media sosial merubah tatanan hidup bermasyarakat, pergaulan atau permainan diwarnai dengan tebak-tebakkan atau oleh orang Manado disebut dengan Cigulu-cigulu. Permainan tebak-tebakkan ini sangat menarik karena mengajar lawan bicara untuk berpikir dan menebak apa yang menjadi pertanyaan dari pemberi cigulu-cigulu. 
Permainan tradisional ini cukup menarik perhatian pada zamannya. Dalam permainan ini keterkaitan antara pertanyaan dan jawaban sangat erat sehingga orang yang benar-benar kreatif dapat menjawab tebak-tebakan (cigulu-cigulu). Seringkali selesai pertemuan formal (ibadat, rapat, perkumpulan) banyak orang mulai dengan cigulu-cigulu. Perkembangan cigulu-cigulu kemudian menjadi hal yang biasa ditanyakan dalam konteks tertentu.

Umumnya pertanyaan yang diberikan berkaitan dengan hidup kemasyarakatan. Misalnya nama buah, nama toko, nama kue, kota, tempat, dll). Baik pernyataan, pertanyaan atau pun jawaban memiliki keterkaitan dengan nama tersebut di atas. Contoh: tebak apakah jawabannya: "ada tiga basudara kong maso panjara, dorang kaluar babadarah (tiga bersaudara, masuk penjara, keluar berdarah-darah). Apa jawabannya? Jawabannya: makan pinang). Pernyataan ini dapat berkonotasi negatif karena disebut tentang penjara dan darah. "Penjara" berkonotasi negatif, sama halnya juga dengan "darah". Jawabannya justru bermakna positif yaitu "makan pinang." Makan pinang pastinya mulut menjadi merah yang identik dengan darah, sedangkan "mulut" dalam pernyataan di atas diidentikkan dengan "penjara" karena ada tiga bersaudara yang masuk. "tiga bersaudara identik dengan sirih, pinang dan kapur. Walaupun di Manado tidak ditemukan lagi tradisi makan sirih pinang, tetapi justru hal ini mengingatkan akan budaya lain yang masih makan sirih pinang, misalnya di Papua dan NTT.

Mengenai hal ini tentu berkaitan dengan semantik itu sendiri khususnya makna konotatif yang terkandung di dalam leksem. Ketika seorang penutur mulai bermain cigulucigulu, maka terdapat banyak makna konotatif yang diungkapkan lewat bahasa. Sehingga tidak mengherankan bahwa cigulu-cigulu berkaitan erat dengan situasi, kondisi dan ekpresi budaya orang Manado dalam mengungkapkan makna.

Dari segi semantik, cigulu-cigulu sangat menarik untuk ditelaah secara ilmiah, karena berkaitan dengan arti atau makna yang terkandung pada suatu bahasa, kode atau jenis 
representasi lain. Karena itu dalam tulisan ini akan dibahas tentang makna semantik konotatif yang terkandung dalam cigulu-cigulu atau tebak-tebakkan.

Makna kognitif dapat dibedakan dari makna konotatif berdasarkan hubungannya, yaitu hubungan antara kata dengan acuannya atau hubungan kata dengan denotasinya (hubungan antara kata dengan orang, tempat, sifat, proses, dan kegiatan luar bahasa;dan hubungan antara kata (ungkapan) dengan ciri-ciri tertentu yang bersifat konotatif.

Makna konotatif dapat bersifat incidental. Makna emotif (emotive meaning) adalah makna yang melibatkan perasaan (pembicara dan pendengar; penulis dan pembaca) ke arah yang positif. Makna ini berbeda dengan makna kognitif (denotatif) yang menunjukkan adanya hubungan antara dunia konsep (reference) dengan kenyataan, makna emotif menunjukkan sesuatu yang lain yang tidak sepenuhnya sama dengan yang terdapat dalam dunia kenyataan (Djajasudarma, 1993). Suatu kata dapat memiliki makna emotif dan bebas dari makna kognitif atau dua kata dapat memiliki makna kognitif yang sama, tetapi dua kata tersebut dapat memiliki makna emotif yang berbeda. Makna emotif di dalam bahasa Indonesia cenderung berbeda dengan makna konotatif; makna emotif cenderung mengacu kepada hal-hal (makna) yang negatif.

Makna konotatif adalah makna lain yang ditambahkan pada makna denotatif yang berhubungan dengan nilai rasa dari orang atau kelompok orang yang menggunakan kata tersebut. Umpamanya kata babi pada contoh diatas, pada orang yang beragama Islam atau didalam masyarakat Islam mempunyai konotasi yang negatif, ada rasa atau perasaan tidak enak bila mendengar kata itu.

Harimurti (1982: 91) dalam buku Mansoer Pateda, R (2010: 112) berpendapat “aspek makna sebuah atau sekelompok kata yang didasarkan atas perasaan atau pikiran yang timbul atau ditimbulkan pada pembicara (penulis) dan pendengar (pembaca)." Dengan kata lain, makna konotatif merupakan makna leksikal + X. Misalnya, kata amplop. Kata amplop 
bermakna sampul yang berfungsi tempat mengisi surat yang akan disampaikan kepada orang lain atau kantor, instansi, jawatan lain. Makna ini adalah makna denotasinya. Tetapi pada kalimat "Berilah ia amplop agar urusanmu segera selesai," maka kata amplop sudah bermakna konotatif yaitu berilah ia uang.

Peneliti membatasi penelitian tentang Cigulu-cigulu yaitu di Kota Manado pada penutur berumur 35-60 tahun. Materi tentang cigulu-cigulu didapat dari penutur yang secara langsung dalam beberapa perjumpaan atau pertemuan sempat terungkap bermain tebaktebakan atau cigulu-cigulu. Sedangkan yang menjadi lokus penelitian yakni di kota Manado khususnya di beberapa tempat yaitu di kecamatan Tikala dan Wenang.

Berdasarkan uraian tentang cigulu-cigulu,maka yang menjadi rumusan masalah yaitu:

1. Apakah permainan Cigulu-cigulu BMM memiliki makna konotatif?

2. Makna konotatif apa saja yang terkandung dalam Cigulu-cigulu?

3. Bagaimana pengaruh cigulu-cigulu terhadap masyarakat khususnya dalam konteks bahasa Melayu Manado?

Tujuan tujuan yang hendak dicapai adalah:

1. Mengidentifikasi cigulu-cigulu dalam BMM secara konotatif .

2. Mengungkapkan makna yang terdapat pada permainan Cigulu-cigulu secara makna konotatif

3. Menganalisa pengaruh cigulu-cigulu dalam masyarakat khususnya dalam konteks berbahasa Melayu Manado.

Adapun manfaat penelitian yaitu:

1. Manfaat teoritis: Penelitian ini diharapkan dapat memberikan wawasan dalam bidang semantik dalam upaya mengungkapkan makna makna konotatif yang terkandung dalam permainan Cigulu-cigulu sehingga dapat memberikan informasi, gambaran, dan bahan 
referensi sebagai dasar bagi yang akan melakukan penelitian yang ada kaitannya dengan bidang ini.

2. Manfaat praktis: Penelitian ini dapat memberikan sumbangan positif terhadap perkembangan linguistik khususnya pengguna BMM untuk memamahi cigulu-cigulu dengan makna konotatif yang ada .

Pengertian semantik menurut Lyons: Menurut Lyons (1968:400) "The term semantics is of relatively recent origin, being coined in the late nineteenth century froma Greek verb meaning to signify". Maksud dari Lyon adalah istilah asal yang relatif baru, yang diciptakan pada akhir abad kesembilan belas dari arti kata kerja Yunani yang diartikan "untuk menandakan”. Semantik menurut Palmer. Semantics is the techical term used to refer to the study of meaning, and since meaning is part of language, semantics is a linguistic.

Menurut Kridalaksana semantik adalah bagian dari struktur bahasa yang berhubungan dengan makna ungkapan dan dengan struktur makna suatu wicara. Makna adalah maksud pembicaraan, pengaruh satuan bahasa dalam pemahaman persepsi, serta perilaku manusia atau kelompok. Menurut Chaer: (1989:60) bahwa pengertian semantik adalah hubungan antara kata dengan konsep atau makna dari kata tersebut, serta benda atau hal yang dirujuk oleh makna itu yang berada di luar bahasa.

Menurut Tarigan semantik menelaah lambang-lambang atau tanda-tanda yang menyatakan makna, hubungan makna yang satu dengan yang lain, dan pengaruhnya terhadap manusia dan juga masyarakat. jadi, dapat dikatakan bahwa semantik senantiasa berhubungan dengan makna yang digunakan oleh masyarakat penuturnya.Menurut Hurford dan Heasley: pengertian semantik adalah kata semantik sebenarnya istilah teknis yang mengacu pada studi tentang makna bahasa. Menurut KBBI (2005:548), adalah arti, makna, maksud pembicara dan penulis, atau pengertian yang diberikan pada suatu bentuk pembahasan. 
Makna konotatif adalah salah satu jenis makna yang ada dalam kajian semantik. Makna konotatif merupakan makna yang bukan sebenarnya. Makna konotatif terdapat dalam sebuah klausa. Menurut Keraf (1994:29) makna konotatif adalah suatu jenis makna dimana stimulus dan respons mengandung nilai-nilai emosional. Konotasi atau makna konotatif disebut juga makna konotasional, makna emotif, atau makna evaluatif. Makna konotatif sebagian terjadi karena pembicara ingin menimbulkan perasaan setuju atau tidak setuju, senang atau tidak senang, dan sebagainya pada pihak pendengar, dipihak lain kata yang dipilih itu memperlihatkan bahwa pembicaranya juga memendam perasaan yang sama. Makna konotatif sebenarnya adalah makna denotasi yang mengalami penambahan.

Hal ini sependapat dengan pengertian konotasi dalam Kamus Besar Bahasa Indonesia (2008:725) yakni konotasi adalah tautan pikiran yang menimbulkan nilai rasa pada seseorang ketika berhadapan dengan sebuah kata, makna yang ditambahkan pada makna denotasi. Aminuddin (2001:88) berpendapat makna konotatif adalah makna kata yang telah mengalami penambahan terhadap makna dasarnya.

Makna konotatif disebut juga dengan makna tambahan. Makna konotatif muncul sebagai akibat asosiasi perasaan pemakai bahasa terhadap kata yang didengar atau dibaca. Zgusta (dalam Aminuddin, 2001:112) berpendapat makna konotatif adalah makna semua komponen pada kata ditambah beberapa nilai mendasar yang biasanya berfungsi menandai. Harimurti (dalam Aminuddin, 2001:112) berpendapat aspek makna sebuah atau sekelompok kata yang didasarkan atas perasaan atau pikiran yang timbul atau ditimbulkan pada pembicara (penulis) dan pendengar (pembaca).

Sebuah kata disebut mempunyai makna konotatif apabila kata itu mempunyai "nilai rasa", baik positif maupun negatif. Jika tidak memiliki rasa maka dikatakan tidak memiliki konotasi. Tetapi dapat juga disebut berkonotasi netral (Chaer, 1995:65). Dua buah kata atau lebih yang mempunyai makna denotasi yang sama dapat menjadi berbeda makna 
keseluruhannya akibat pandangan masyarakat berdasarkan nilai-nilai atau norma-norma budaya yang berlaku dalam masyarakat tersebut.

Positif dan negatifnya nilai rasa sebuah kata seringkali juga terjadi sebagai akibat digunakannya referen kata itu sebagai sebuah perlambang. Jika digunakan sebagai lambang sesuatu yang positif maka akan bernilai rasa yang positif, dan jika digunakan sebagai lambang sesuatu yang negatif maka akan bernilai rasa negatif. Misalnya, burung garuda karena dijadikan lambang negara republik Indonesia maka menjadi bernilai rasa positif sedangkan makna konotasi yang bernilai rasa negatif seperti buaya yang dijadikan lambang kejahatan. Padahal binatang buaya itu sendiri tidak tahu menahu kalau dunia manusia Indonesia menjadikan mereka lambang yang tidak baik.

Berdasarkan beberapa pendapat di atas, dapat disimpulkan makna konotatif adalah makna yang tidak sebenarnya, makna yang telah mengalami penambahan pada makna dasarnya, yakni hanya tambahan yang sifatnya memberi nilai rasa, baik positif maupun negatif. Makna konotatif atau konotasi kata mengacu pada makna kias atau makna bukan sebenarnya. makna konotatif mengandung imajinasi, nilai rasa, dan dimaksudkan untuk menggugah rasa.

Menurut pendapat Tarigan (1985:60) ragam konotasi dibagi menjadi dua macam, yaitu konotasi baik dan konotasi tidak baik.

a). Konotasi baik.

Kata-kata yang mempunyai konotasi baik dan oleh sebagian masyarakat dianggap memiliki nilai rasa yang lebih enak, sopan, akrab, dan tinggi. Konotasi baik dibagi menjadi dua macam, yaitu 1) konotasi tinggi, dan 2) konotasi ramah.

Konotasi tinggi yaitu kata - kata sastra dan kata - kata klasik yang lebih indah dan anggun terdengar oleh telinga umum. Kata-kata seperti itu mendapat konotasi atau nilai rasa 
tinggi. Kata-kata klasik yang apabila orang mengetahui maknanya dan menggunakan pada konteks yang tepat maka akan mempunyai nilai rasa yang tinggi.

Konotasi ramah yaitu kata-kata yang berasal dari dialek atau bahasa daerah karena dapat memberikan kesan lebih akrab, dapat saling merasakan satu sama lain, tanpa ada rasa canggung dalam bergaul. Berdasarkan pengertian di atas, dapat disimpulkan bahwa indikator konotasi ramah pada sebuah kata adalah sebagai berikut:

a. Kata-kata berasal dari dialek: Kata-kata tidak menimbulkan rasa canggung dalam bergaul.

b. Konotasi tidak baik. Konotasi tidak baik berarti kata-kata yang oleh sebagian masyarakat dianggap memiliki nilai rasa tidak sopan, tidak pantas, kasar, dan dapat menyinggung perasaan orang lain. Konotasi tidak baik dibagi menjadi lima macam, antara lain:

1) konotasi berbahaya: Konotasi berbahaya yaitu kata-kata yang erat kaitannya dengan kepercayaan masyarakat kepada hal-hal yang sifatnya magis.

2) konotasi tidak pantas, Konotasi tidak pantas yaitu kata-kata yang diucapkan tidak pada tempatnya dan mendapat nilai rasa tidak pantas, sebab jika diucapkan kepada orang lain maka orang lain tersebut akan merasa malu, merasa diejek dan dicela.

3) konotasi tidak enak, Konotasi tidak enak yaitu salah satu jenis konotasi atau nilai rasa tidak baik yang berkaitan erat dengan hubungan sosial dalam masyarakat.

4) konotasi kasar yaitu kata-kata yang terdengar kasar dan mendapat nilai rasa kasar. Katakata kasar dianggap kurang sopan apabila digunakan dalam pembicaraan dengan orang yang disegani.

5) konotasi keras. Konotasi keras yaitu kata-kata atau ungkapan-ungkapan yang mengandung suatu pernyataan yang berlebihan, dengan membesar-besarkan sesuatu hal.

Bertolak dari beberapa pendapat di atas, maka dapat disimpulkan bahwa makna konotatif adalah makna yang telah mengalami penambahan pada makna dasarnya, yakni tambahan yang sifatnya memberi nilai rasa, baik positif maupun negatif. 


\section{METODOLOGI PENELITIAN}

Berdasarkan rumusan masalah dan tujuan penelitian yang hendak dicapai, maka jenis penelitian yang digunakan dalam penelitian ini adalah deskriptif kualitatif, karena penelitian ini mendeskripsikan suatu objek yang akan diteliti yaitu tentang makna semantik yang terkandung pada cigulu-cigulu BMM. Penelitian kualitatif adalah penelitian yang bermaksud untuk memahami fenomena apa yang dialami oleh subjek penelitian misalnya perilaku, presepsi, motivasi, dan lain-lain dengan cara deskripsi dalam bentuk kata-kata dan bahasa pada suatu konteks khusus yang alamiah dan dengan memanfaatkan metode alamiah (Moleong, 2006:6).

Teknik Pengumpulan data yang digunakan dalam penelitian ini yaitu dengan metode simak. Metode penyediaan data ini diberi nama metode simak karena cara yang digunakan untuk memperoleh data dilakukan dengan menyimak penggunaan bahasa (Mahsun, 2012:92). Menurut Mahsun Apabila peneliti berhadapan dengan penggunaan bahasa secara tertulis, maka dalam penyadapan itu peneliti hanya dapat menggunakan teknik catat, yaitu mencatat beberapa bentuk yang relevan bagi penelitiannya dari penggunaan bahasa secara tertulis tersebut.

Langkah pertama dalam pengumpulan data yaitu penulis menentukan judul penelitian, setelah itu peneliti mengumpulkan data dengan bertemu orang-orang yang masih bermain tebak-tebakkan dan juga studi kepustakaan melalui internet. Kemudian peneliti mengidentifikasi dan menggolongkan kategori cigulu-cigulu. Selanjutnya, penyimakan kemudian dicatat untuk memperoleh data. Penelitian ini menggunakan triangulasi data dan triangulasi teori.

Menggunakan triangulasi data yakni, peneliti menggunakan beberapa sumber data untuk mengumpulkan data yang sama. Data yang diperoleh dicek ulang pada sumber data lain. Peneliti mengumpulkan beberapa sumber data yang mengupas tentang cigulu-cigulu 
yang telah diperoleh dicek kembali pada sumber data lain untuk diperoleh kebenarannya dan kesamaanya. Triangulasi teori, yaitu data yang terkumpul dapat diperiksa derajat kepercayaannya dengan satu atau lebih teori sebagai perbandingan. Data yang digunakan dalam penelitian adalah data kualitatif. Analisis data dalam penelitian ini dilakukan dengan mengidentifikasi dan mengelompokkan berdasarkan kategori cigulu-cigulu yang ditemukan, serta dilanjutkan dengan analisis dan penarikan kesimpulan.

Hasil analisis data dan pembahasan yang merupakan jawaban atas masalah yang hendak dicapai, hendaknya disajikan secara teori. Penyajian hasil analisis atau temuan diatas dilakukan dengan menggunakan dua metode, kedua metode ini adalah metode formal dan informal (Mahsun, 2012:279). Dalam penelitian ini menggunakan metode informal. Metode penyajian informal adalah penyajian hasil analisis data yang menggunakan kata-kata biasa (Kesuma, 2007:14).

\section{HASIL PENELITIAN DAN PEMBAHASAN}

Pada bagian awal telah terungkap bahwa makna konotatif terdiri atas 2 bagian yaitu konotatif positif dan negatif. Pada konotasi baik atau positif terbagi atas 2 bagian yaitu konotasi tinggi dan ramah, sedangkan konotasi tidak baik terdiri atas beberapa bagian seperti: konotasi berbahaya, tidak pantas, tidak enak, kasar, keras.

Berikut penggolongan cigulu-cigulu berdasarkan makna konotasinya:

\section{Konotasi Positif:}

Cigulu-cigulu "Pa depe buah da daong, di daong da buah (di buah ada daun, di daun ada buah), apakah itu"? Jawabannya Nanas. Frasa dengan Tata bahasa relasional tersebut memiliki makna positif, karena berbicara tentang buah dan daun; jawabannya juga tidak lepas dari buah-buahan yaitu buah Nanas. Hal ini menjadi hal biasa karena di Manado terdapat buah Nanas yang berbuah sepanjang tahun dan tidak dikenal sebagai buah musiman. 
Contoh berikut ini berkaitan dengan makanan yaitu kue. Kukis apa yang depe tenga nya' bisa makan (Kue apa yang tengahnya tidak dapat dimakan? Jawabannya yaitu donat. Pertanyaan tersebut secara gamblang hendak menghubungkan antara kue yang memiliki lubang di tengah. Di Manado di kenal dengan kue donat yang tengahnya berlubang. Secara otomatis kita dapat berpikir bahwa kalau tengahnya berlubang berarti tidak dapat dimakan. Sejak dulu kue ini dikenal dalam budaya orang Manado yang mengkonsumsi kue ini pada saat minum pagi/sore ataupun ketika sedang acara atau pesta. Kebiasaan makan kue ini membuat orang tertarik untuk menjadikan cigulu-cigulu.

Cigulu-cigulu berikut ini menggambarkan tentang pertanyaan bermakna positif tetapi jawabannya justru bermakna negatif. "Binatang apa depe mata deng kaki samua di kapala? (Binatang apa yang mata dan kaki di kepala?). Jawabannya Kutu. Klausa tersebut bersifat positif sedangkan jawabannya negatif. Mengapa? Kutu identik dengan kepala yang tidak bersih, kotor. Kutu adalah binatang yang cukup menjijikkan untuk sebagian orang. Masih banyak ditemukan pada budaya tertentu tentang mencari kutu pada saat senggang atau waktu luang. Kebanyakan budaya ini dibuat oleh orang tua terhadap anaknya, baik anak laki-laki maupun perempuan. Hal ini sebenarnya dapat juga mengungkapkan bagaimana perhatian ibu terhadap kebersihan anaknya. Ibu memastikan bahwa anaknya tidak menggaruk kepala yang dapat mengakibatkan luka karena kutu. Zaman dulu belum ada shampo yang dapat digunakan untuk mencuci rambut dengan bersih. Kesempatan mencari kutu bahkan menjadi kebiasaan.

Cigulu-cigulu yang agak sulit karena harus memahami dengan baik dan benar budaya Manado terdapat pada contoh berikut ini: "4 huruf nama makanang, tambah 2 huruf, jadi nama minumang, apakah itu? (4 huruf nama makanan, tambah 2 huruf, jadi nama minuman, apakah itu?) Jawabannya saguer $=$ sagu 4 huruf, tambah 2 huruf jadi saguer). Menarik untuk diteliti secara linguistik contoh cigulu-cigulu seperti ini. Sagu adalah Frasa Nomina, ditambah dengan 2 huruf tetap menjadi Frasa Nomina yaitu saguer. Frasa ini terjadi bukan 
karena perubahan fonem, tetapi penambahan fonem -er menjadi sagu-er. Perubahan ini dikategorikan sebagai infleksi karena tidak mengalami perubahan kelas kata; FN tetap menjadi FN. Cigulu-cigulu tersebut memiliki makna positif karena tidak ada yang berkonotasi negatif, tetapi jawaban atas pertanyaan tersebut lebih bermakna negatif, karena diidentikkan dengan minuman beralkohol khas asal Sulawesi Utara. Saguer diambil dari pohon Aren. Rasanya manis bercampur asam dan mengandung alkohol dengan kadar yang rendah (4-5\% kadar alkohol). Ketika masih segar minuman ini mengeluarkan busa. Saguer maknanya menjadi negatif karena dari saguer lahirlah "cap tikus" atau minuman dengan kadar alkohol yang tinggi sehingga yang minum dapat mabuk.

Dari sejarah kebudayaan Minahasa seperti yang ditulis oleh Jessy Wenas disebutkan bahwa terdapat 3 dewa saguer yaitu dewa-dewa minuman alkohol. Mereka adalah Makawiley, Kiri Waerong dan Parengkuan. Kiri Waelong dikaitkan dengan pembuatan gula merah dari saguer yang dimasak dan Parengkuan dihubungkan dengan air saguer. Dalam buku Graafland berjudul "De Minahasa" ditulis: "Het is de drank der Empung en Kasuruan, een godendrank, die bijna voor heilig gehouden wordt, de saguwer" (itu adalah, minuman para Empung dan Kasuruan, leluruh dan dewa-dewa, minuman dewata, minuman yang hampir dianggap suci: saguer.”

\section{Konotasi Negatif:}

Contoh cigulu-cigulu dengan konotasi negatif yaitu: "Bukalah penetiku dan bukalah bajuku dan buanglah aku ke lubang yang gelap.” Jawabannya Kue Lalampa atau Koyabu. Kalimat pernyataan bermakna negatif tetapi jawabannya tidak bermakna negatif. Jawaban justru berkaitan dengan nama makanan atau kue khas Manado yang disebut dengan Lalampa atau Koyabu. Seakan-akan cigulu-cigulu tersebut berkonotasi sensual, "bukalah penetiku, bukalah bajuku." Secara keseluruhan justru orang Manado yang mendengar kalimat tersebut 
dapat berpikir negatif atau tidak nyaman karena kata-katanya agak vulgar untuk diungkapkan. Tetapi untuk orang Manado hal tersebut adalah biasa saja. Karena jawabannya juga tidak bermakna vulgar apalagi terkait dengan seksualitas. Hal ini dapat menjadi indikasi bahwa untuk orang Manado pembicaraan seperti ini bukanlah sesuatu yang "tabu". Justru hal ini menjadi kebiasaan untuk mengungkapkan secara langsung. Kue lalampa dibungkus menggunakan daun pisang yang sudah dibuat lemas oleh panas api. Oleh orang yang bermain cigulu-cigulu daun pisang ini diidentikkan dengan baju. Sedangkan untuk merekatkan daun pisang menggunakan kayu kecil yang disebut dengan peneti. Sama halnya juga dengan kue koyabu. Kue ini dibungkus dengan daun pandan dan direkatkan dengan menggunakan kayu kecil. Sampai sekarang kedua kue ini sangat digemari di Manado karena rasanya yang enak dan gurih karena lalampa menggunakan ikan sedangkan koyabu berisi gula merah khas Manado.

"Kapala bota di atas daong" (Kepala gundul di atas daun). Jawabannya adalah kue Biapong. Orang yang mendengar klausa ini dapat tersinggung apalagi ditujukan kepada orang yang benar-benar gundul. Kepala sudah gundul diletakkan di atas daun. Ternyata daun yang dimaksudkan pada klausa ini adalah daun pisang. Jawaban atas pernyataan ini sangatlah menggelitik. Memiliki nilai humor tetapi harus hati-hati dalam penyampaian karena dapat membuat orang lain tersinggung. Sama halnya dengan makna positif di atas bahwa jawabannya atas pernyataan ini yaitu kue khas Manado; kue biapong. Biapong tampilannya gundul putih mengkilat dan biasanya diletakkan di atas daun supaya tidak menempel. Kue ini oleh orang Manado sering dijumpai entah acara pesta, pertemuan, ibadat, perjamuan atau sekedar minum pagi/sore di rumah.

Kalu tidor badiri, kalo badiri dia tidor (kalau tidur berdiri, kalau berdiri tidor) jika orang yang mendengar frasa ini akan mengidentikkan dengan sesuatu yang tabu karena 
merujuk pada hal yang bersifat seksual. Jawabannya justru jauh dari kata seksual atau tabu. Jawabannya adalah jari kaki.

\section{SIMPULAN DAN SARAN}

Cigulu-cigulu adalah sebuah permainan yang cukup membuka pemahaman baik secara kognitif, afektif maupun psikomotor. Dari segi linguistik banyak hal yang dapat diteliti karena berkaitan dengan makna semantik dan juga etnografi setiap budaya. Di beberapa budaya memiliki permainan seperti ini, tetapi yang berbeda adalah dalam BMM menggunakan budaya yang justru lahir dari kebiasaan orang Manado yang senang dengan makanan (kue) dan juga mengungkapkan hal-hal yang mengarah pada seksualitas. Untuk budaya tertentu hal ini masih tabu, tetapi untuk pengguna BMM hal seperti ini tidak menjadi masalah karena diungkapkan oleh berbagai kalangan dari anak-anak sampai orang dewasa. Ini juga menunjukkan bahwa orang Manado tergolong "terbuka", tidak menutup-nutupi melalui cigulu-cigulu memudahkan orang bergaul, berteman, berkelompok atau hidup bermasyarakat. Penelitian seperti ini akan sangat menarik kalau dapat diteliti dari sudut pandang yang lain sehingga memperkaya khazanah linguistik yang lahir dari budaya lokal setiap daerah.

\section{Daftar Pustaka:}

Abdul Chaer, 2015, Sintaksis Bahasa Indonesia, Rineka Cipta: Jakarta.

Comrie, Bernard. 1988. Linguistik Tipology dalam F.J. Newmeyer (ed) Linguistic: The Cambridge

Comrie, Bernard. 1983, 1989. Language Universals and Linguistik Tipology. Oxford: Basil Blackwell Publisher Limited.

Dr. Hasan Busri, M.Pd, Dr. Moh. Badrih, S.Pd, M.Pd, Linguistik Indonesia, Madani Media, 2018. 
H.A.Gleason Jr, 1961, An Introduction to Descriptive Linguistics, United State America, Survey. Vol. 1 Hal 447-467. Cambridge: Cambridge University Press.

John I. Saeed, 1997, Semantiks, Blackwell Publishing, Oxford, UK.

John Lyons, 1981, Language and Linguistics, Cambridge New York.

Keraf, Gorys. 1990. Linguistik Bandingan Tipologis. Jakarta: PT Gramedia.

Mallinson, Graham dan Barry J. Blake, 1981. Language Typology: Cross-Linguistik Studies In Syntax. Amsterdam: North-Holland Publishing Company.

Moleong. 2004. Metode Kualitatif. Bandung: Rosdakarya.

Nick Riemer, 2010, Introducing Semantiks, Cambridge University Press.

Mahsun, MS, Metode Penelitian Bahasa: Tahapan Strategi, metode dan Tekniknya, PT RajaGrafindo Persada, 2005.

Matthews, P.H., Morphology, An Introduction to the Theory of Word-Structure, Cambridge, 1978.

Song Jae Jung, Linguistic Typology, Morphology and Syntax, Pearson Education Asia Ptc Ltd, 2001. 